九州大学学術情報リポジトリ

Kyushu University Institutional Repository

\title{
Genetic Diversity of Soybean Genotypes revealed by Agro-morphological and SSR markers
}

Khatab, Ismael A.

Department of Genetics, Faculty of Agriculture, Kafrelsheikh University

Morsy, Akram R.

Legumes Department, Institute of Filed Crop Research, Agricultural Research Center

Fares, Waleed M.

Central Laboratory of Design and Statistical Analysis Research, Agricultural Research Center

Kumamaru, Toshihiro

Plant Genetics Laboratory, Institute of Genetic Resources Faculty of Agriculture, Kyushu University

https://doi.org/10.5109/1564086

出版情報：九州大学大学院農学研究院紀要. 61 (1)，pp.79-87，2016-02-29. Faculty of Agriculture， Kyushu University

バージョン :

権利関係 : 


\title{
Genetic Diversity of Soybean Genotypes revealed by Agro-morphological and SSR markers
}

\author{
Ismael A. KHATAB ${ }^{1 *}$, Akram R. MORSY ${ }^{2}$, Waleed M. FARES ${ }^{3}$ \\ and Toshihiro KUMAMARU ${ }^{4}$
}

\author{
${ }^{1}$ Department of Genetics, Faculty of Agriculture, Kafrelsheikh University, 33516, Egypt. \\ ${ }^{2}$ Legumes Department, Institute of Filed Crop Research, Agricultural Research Center, Egypt. \\ ${ }^{3}$ Central Laboratory of Design and Statistical Analysis Research, Agricultural Research Center, Egypt. \\ ${ }^{4}$ Plant Genetics Laboratory, Institute of Genetic Resources Faculty of Agriculture, \\ Kyushu University, Hakozaki 6-10-1, Fukuoka 812-8581, Japan \\ (Received November 16, 2015 and accepted November 19, 2015)
}

\begin{abstract}
Increasing the diversity of the soybean germplasm base could introduce new genes affecting agronomic traits. In this study, we demonstrated the differences of genetic diversity level among 24 soybean genotypes and adapt an augmented design to screen and select the superior entries among 24 soybean germlasm and to calculate similarity parameters. Likewise, to elucidate the relationships based on molecular markers among new promising lines and introduced genotypes with improved Egyptian commercial cultivars using SSR markers, to use this information in future breeding programs. The results exhibited significant differences among the tested genotypes for all studied characters. This provides evidence for the possibility to carry out a sufficient selection program on the basis of these traits using the studied genotypes. Thirteen out 14 SSR primer pairs amplify polymorphic SSRs from all of these genotypes, a total of 42 alleles were produced. The polymorphic information content (PIC) among genotypes varied from 0.55 (satt001) to 0.88 (satt173) with 2 and 5 alleles respectively. However, Satt005 produced only one monomorphic band. The used SSR primer pairs successfully distinguished most of soybean genotypes, with the exception of a pair of closely related breeding lines from the same cross. The genetic relationships among genotypes based agromorphological analysis not completely agreed with known pedigrees. However, phylogenetic tree based on SSR confirmed the separation of soybean genotypes into six clusters and were more clearly separated. These results suggest that SSR markers are efficient for measuring genetic diversity and relatedness as well as identifying varieties of soybeans.
\end{abstract}

Key words: Glycine max, polymorphism, phylogenetic tree, SRAP, SSR

\section{INTRODUCTION}

Soybean [Glycine $\max$ (L.) Merr.] is one of the most frequently cultivated crops worldwide. It is important for both protein meal and vegetable oil in addition it is rich in lysine and vitamins and is used for both human and animal consumption as well as for industrial purposes, such as biofuels (Hartman et al., 2011). One of the prerequirements for soybean successful breeding strategies for biotic and or a biotic stress is the complete understanding of the genetic diversity of this crop. The augmented designs were proposed by Federer (1956) to permit the early assessment of many new varieties when no replicated trial is possible due to paucity of seed material and limitations of introduced or lines seeds, it has been used in field screening trials of soybean (Spehar, 1994). Genetic relationships among number of tested

\footnotetext{
1 Department of Genetics, Faculty of Agriculture, Kafrelsheikh University, 33516, Egypt.

2 Legumes Department, Institute of Filed Crop Research, Agricultural Research Center, Egypt.

3 Central Laboratory of Design and Statistical Analysis Research, Agricultural Research Center, Egypt.

${ }^{4}$ Plant Genetics Laboratory, Institute of Genetic Resources Faculty of Agriculture, Kyushu University, Hakozaki 6-10-1, Fukuoka 812-8581, Japan.

* Corresponding author. Ismael A. Khatab, Tel: +2 0190147275 (E-mail: ismael.khatab@yahoo.com)
}

genotypes can be measured by similarity using number of quantitative characters which meaning that the differences among characters of tested genotypes attributed to the genetic divergence of these genotypes in soybean Iqbal et al. (2008) and Ojo et al. (2012). Several methods have been used to investigate the genetic variation in soybean. Morphological and agronomic traits have been employed (Perry and McIntosh, 1991; Sneller et al., 1997). As in other major crops, genetic diversity of soybean grown is very narrow (Brown-Guedira et al. 2000), and has been decreasing at an alarming rate. The narrow genetic base of soybean cultivars has been confirmed in many studies based on pedigree analysis (Delannay et al., 1983; Gizlice et al., 1994) or molecular markers (Narvel et al., 2000; Thompson et al., 1998; Khatab and Morsy, 2012).

At present, the use of exotic germplasm in soybean cultivar development generally has been limited to a small number of introductions (introduced) that have served as sources of genes for resistance to biotic and/or a biotic stress. To efficiently broaden the genetic base of soybean cultivars a detailed insight into genetic diversity of soybean resources is required. Such insight could be achieved through molecular characterization using DNA markers, which are more informative, stable and reliable, compared to pedigree analysis and traditionally used biochemical markers. Microsatellites or simple sequence repeat markers (SSR) are being extensively used in 
genome studies, marker assisted selection, and cultivar identification and are well-known for their versatility in providing a quick assay and for their highly informative data (Prioli et al., 2002; Abe et al., 2003; Wang et al., 2006; Fu et al., 2007; Tantasawat et al., 2011). It have been widely applied in the genetic diversity studies of the soybean germplasm (Meesang et al., 2001; Abe et al., 2003; Fu et al., 2007; Li et al., 2008; Yoon et al., 2009; Zhenbin et al., 2014). Genetic relationships among accessions are helpful for designing future breeding efforts for crop improvement (Wang et al., 2006). Complete description of existing certified soybean varieties and patterns of genetic diversity could facilitate introgression of diverse germplasm into the current commercial soybean genetic base (Tara et al., 2006).

To date, there is little information are available regarding genetic varia $\neg$ tion in Egyptian soybean. Recently Khatab and Morsy (2012) used ISSR and morphological traits used to evaluate genetic diversity in six Egyptian soybean genotypes and reported that narrow genetic diversity were found among the studied genotypes. However, more and intensive work still needed to draw clear image about most common soybean genotypes grown in Egypt using more informative markers and more genotypes. The objectives of the present study were to adapt an augmented design to screen and select the superior entries among 24 soybean germlasm and to calculate similarity parameters among soybean genotypes using cluster analysis and elucidate the relationships based on molecular markers among new promising lines with improved Egyptian commercial cultivars using SSR markers, to use this information in future breeding programs.

\section{MATERIALS AND METHODS}

\section{Plant Materials}

The materials consisted of 24 genotypes of soybean (20 tested genotypes; cultivars, introduced genotypes and promising lines; and four check varieties being Giza 35, Giza 83, Giza 111 and Crawford) for yield and some agronomic traits. The experiment was grown in augmented design at Sakha Research Station during the 2015 season with six blocks. The experimental plot consisted of 2 ridges, $3 \mathrm{~m}$ long and $70 \mathrm{~cm}$ apart, spacing between plants at $15 \mathrm{~cm}$. At harvest, five guarded plants were randomly taken from each plot to measure plant height $(\mathrm{cm})$, number of branches per plant, number of pods per plant and 100-seed weight (g). Seed yield was determined using the full plot area and then converted to the unit of ton/fed. The details of pedigree and some seed proper-

Table 1. Name, Pedigree and some morphological properties for 24 soybean genotypes

\begin{tabular}{|c|c|c|c|c|c|c|}
\hline No. & Genotypes & Pedigree & $\begin{array}{l}\text { Maturity } \\
\text { group }\end{array}$ & Stem Termination & Flower color & $\begin{array}{l}\text { Flower date } \\
\text { (day) }\end{array}$ \\
\hline 1 & Giza 21 & Crawford $\times$ Celest & IV & Indeterminate & Purple & 39 \\
\hline 2 & Giza 22 & Crawford $\times$ Forrest & IV & Indeterminate & Purple & 41 \\
\hline 3 & Giza 35 & Crawford $\times$ Celest & III & Indeterminate & Purple & 39 \\
\hline 4 & Giza 82 & Crawford $\times$ Mable Presto & IV & Indeterminate & Purple & 37 \\
\hline 5 & Giza 111 & Crawford $\times$ Celest & IV & Indeterminate & Purple & 41 \\
\hline 6 & Clark & Lincoln $\times$ Richland & IV & Indeterminate & Purple & 37 \\
\hline 7 & Holladay & $\begin{array}{l}\text { N77-179(N70-1549 } \times \\
\text { N72-3213) } \times \text { Johanston }\end{array}$ & VI & Determinate & Purple & 59 \\
\hline 8 & Crawford & Williams $\times$ Columbus & IV & Indeterminate & Purple & 41 \\
\hline 9 & $\mathrm{H}_{30}$ & Crawford $\times$ L62-1686 & IV & Indeterminate & Purple & 41 \\
\hline 10 & $\mathrm{H}_{32}$ & Giza $21 \times$ L86K-73 & IV & Indeterminate & White & 40 \\
\hline 11 & H 105 & Giza $35 \times$ Lamar & $\mathrm{V}$ & Indeterminate & Purple & 42 \\
\hline 12 & $\mathrm{H}_{113}$ & Giza $21 \times$ Major & $\mathrm{V}$ & Indeterminate & Purple & 34 \\
\hline 13 & H 127 & D89-8940 × Giza 82 & III & Indeterminate & Purple & 30 \\
\hline 14 & H 155 & Giza $83 \times$ Giza 21 & IV & Indeterminate & Purple & 34 \\
\hline 15 & H 162 & Toano $\times($ L86K $-73 \times$ Toano $)$ & $\mathrm{V}$ & Indeterminate & Purple & 42 \\
\hline 16 & $\mathrm{H}_{1} \mathrm{~L}_{1}$ & DR $101 \times$ Giza 22 & $\mathrm{~V}$ & Indeterminate & Purple & 44 \\
\hline 17 & $\mathrm{H}_{2} \mathrm{~L}_{3}$ & Clark $\times$ Ware & VI & Indeterminate & Purple & 53 \\
\hline 18 & $\mathrm{H}_{6} \mathrm{~L}_{1}$ & Giza $83 \times$ Ware & IV & Indeterminate & Purple & 46 \\
\hline 19 & $\mathrm{H}_{2} \mathrm{~L}_{24}$ & Crawford $\times$ Celest & IV & Indeterminate & Purple & 44 \\
\hline 20 & $\mathrm{H}_{11} \mathrm{~L}_{8}$ & Ware $\times$ L86K-73 & VI & Indeterminate & Purple & 50 \\
\hline 21 & $\mathrm{H}_{11} \mathrm{~L}_{145}$ & Giza 111 × HC83-123-9 & $\mathrm{V}$ & Indeterminate & Purple & 47 \\
\hline 22 & $\mathrm{H}_{15} \mathrm{~L}_{5}$ & Crawford × D79-10426 & IV & Indeterminate & Purple & 40 \\
\hline 23 & HC83-123-9 & Pixie × PI 229358 & VI & Determinate & Purple & 47 \\
\hline 24 & AGS-129 & Shish Shish $\times$ SRF400 & VI & Indeterminate & Purple & 51 \\
\hline
\end{tabular}


ties for the studied genotypes are presented in Table (1)

\section{Molecular Analysis}

SSR-PCR Amplification

DNA was isolated by CTAB method (Doyle and Doyle, 1990). The primers used were used in this study and the nucleotide sequences of the primers are listed in Table 2. PCR reaction for SSR analysis were done in a volume of $20 \mu \mathrm{l}$ using $40 \mathrm{ng}$ genomic DNA, $0.2 \mathrm{mM}$ dNTP, $1.5 \mathrm{mM} \mathrm{MgCl}_{2}, 10 \mathrm{pmol}$ of each primer (forward and reverse) and $0.5 \mathrm{U}$ Taq polymerase. PCR conditions were as follow: $96^{\circ} \mathrm{C}$ for $1 \mathrm{~min}, 35$ cycles of $96^{\circ} \mathrm{C}$ for $30 \mathrm{~s}$, $55-57^{\circ} \mathrm{C}$ (according primer annealing $\mathrm{Tm}$ ) for $30 \mathrm{sec}$, $72^{\circ} \mathrm{C}$ for $45 \mathrm{sec}$ ) and $72^{\circ} \mathrm{C}$ for $7 \mathrm{~min}$. The reproducibility of the amplification products was checked twice for each primer. After amplification, a $10 \mu \mathrm{l}$ aliquot of the amplified SSR samples was combined with $2 \mu \mathrm{l}$ of a loading buffer $(0.4 \%(\mathrm{w} / \mathrm{v})$ bromo-phenol blue and analyzed directly on $2 \%(\mathrm{w} / \mathrm{v})$ agarose gels in $1 \times \mathrm{TAE}$ buffer (10 mM Tris-Borate, $1 \mathrm{mM}$ EDTA) containing $0.5 \mu \mathrm{g}$ per $\mathrm{ml}$ of ethidium bromide. A $100 \mathrm{bp}$ DNA ladder was used as a size marker to compare the molecular weights of amplified products. After electrophoresis, the gels were documented using Gel Documentation System.

\section{Data Analysis}

Agro-morphological analysis, ANOVA belong to augmented design was carried out according to the procedure outlined by Federer (1956), the resulted mean square error is used to estimate four orders of least significant differences (LSD). Genotypes were clustered using un-weighted pair group method using arithmetic average as outlined by Kovach (1995).

Molecular analysis, the amplified bands from SSR were scored under the heading of total scorable fragments. For each of the defined loci, SSR allelic composition was determined for each genotype. Polymorphism information content (PIC) values which indicating the ability to distinguish between genotypes for each primer was determined according to the formula described by Anderson et al. (1993). Cluster analysis was based on similarity matrix obtained with un-weighted pair group method using arithmetic average (UPGMA), and the relationships between genotypes were displayed as dendrogram calculated based on Jukes-Cantor coefficient using PAST program adapted by Hammer et al. (2001).

\section{RESULTS AND DISCUTION}

Genetic diversity of soybean was assessed using both quantitative and qualitative traits and their cluster analyses are shown in Table 3, it showed the mean values of 20 tested genotypes (adjusted after discarding the block effect) and four check varieties for seed yield and some related characters. The results exhibited significant differences among the tested genotypes for all studied characters. This provides an evidence for the possibility to carry out a sufficient selection program on the basis of these traits using the studied genotypes. The results clearly indicated that the tested genotypes differed significantly in plant height, genotypes H30 and H113 gave the tallest plants and recording $118.50 \mathrm{~cm}$ while Holladay and HC83-123-9 had the shortest plants recording $58.5 \mathrm{~cm}$. The short genotypes are preferable with the aim of applying mechanical management of agricultural practice.

Regarding the number of branches per plant, H162 produced the highest number of branches (4.3) and ranked the first over all tested genotypes and check cultivars followed by Clark and H15L5 (4.05). Increasing the number of branches per plant means that the leaf surface would be more capable to enhance photosynthentic activity which translated in seed formation. Genotypes; H6L1 and H2L24 recorded the lowest number of branches

Table 2. Primers name, sequences and core motif

\begin{tabular}{llll}
\hline primer name & \multicolumn{1}{c}{ sequence $(5->3$ ') Farward } & \multicolumn{1}{c}{ sequence $(5 ’>3$ ') Reverse } & Core motif \\
\hline Satt001 & AAAGTCTTTAAAAGTGTGTCTTA & TTAAAAGAAAAATGCAACAT & (ATT) 25 \\
Satt002 & TGTGGGTAAAATAGATAAAAAT & TCATTTTGAATCGTTGAA & (ATT) 25 \\
Satt005 & TATCCTAGAGAAGAACTAAAAAA & GTCGATTAGGCTTGAAATA & (ATT) 19 \\
Satt009 & CCAACTTGAAATTACTAGAGAAA & CTTACTAGCGTATTAACCCTT & (ATT) 14 \\
Satt030 & AAAAAGTGAACCAAGCC & TCTTAAATCTTATGTTGATGC & (ATT) 21 \\
Satt031 & TTCCACTTTGTATCACTTTC & TGACTGTAAAAGAACAGATAAA & (ATT) 12 \\
Satt173 & TGCGCCATTTATTCTTCA & AAGCGAAATCACCTCCTCT & (ATT) 18 \\
Satt181 & TGGCTAGCAGATTGACA & GGAGCATAGCTGTTAGGA & (ATT) 18 \\
Satt324 & GTTCCCAGGTCCCACCATCTATG & GCG TTT CTT TTA TAC CTT CAA G & (ATT) 19 \\
Satt250 & CGCCAGCTAGCTAGTCTCAT & AATTTGCTCCAGTGTTTTAAGTT & (ATT) 16 \\
Satt268 & TCAGGGGTGGACCTATATAAAATA & CAGTGGTGGCAGATGTAGAA & (ATT) 17 \\
Sat_036 & GCGACTCCAAGTTTTTTTGTTT & GCGGGAGTTAGAGGAAGAGAACA & (AT) 19 \\
Sat_168 & TGTGGATAAAAGAGCATTCAAAATG & GCGATCCTTGTTTATCTCAAAAAAGTGT & (AT) 15 \\
Sat_185 & GCGGCTGGAGAAAACCTTTTATG & GCGAATAAAAACCGAGAATGATTT & (AT) 31 \\
\hline
\end{tabular}


Table 3. Mean values of 20 tested genotypes (adjusted after discarding the block effect) and four check varieties for seed yield and some related characters

\begin{tabular}{|c|c|c|c|c|c|}
\hline Genotypes & $\mathrm{PH}^{*}$ & NOB* & NOP* & $100-\mathrm{SW}^{*}$ & SY* \\
\hline \multicolumn{6}{|l|}{ Tested genotypes } \\
\hline Giza 21 & 108.50 & 3.05 & 148.75 & 20.78 & 1.80 \\
\hline Giza 22 & 103.50 & 2.05 & 167.75 & 16.17 & 2.52 \\
\hline Clark & 78.50 & 4.05 & 126.75 & 16.89 & 0.68 \\
\hline Holladay & 58.50 & 2.05 & 40.75 & 18.91 & 1.88 \\
\hline H30 & 118.50 & 2.30 & 45.00 & 21.09 & 0.70 \\
\hline H32 & 103.50 & 2.30 & 81.10 & 18.75 & 1.25 \\
\hline H 105 & 113.50 & 3.30 & 109.25 & 16.95 & 1.38 \\
\hline H113 & 118.50 & 2.30 & 115.00 & 21.17 & 0.91 \\
\hline H 127 & 79.75 & 2.30 & 113.75 & 17.43 & 1.69 \\
\hline Н 153 & 79.75 & 3.30 & 102.75 & 18.55 & 2.33 \\
\hline H 162 & 104.75 & 4.30 & 69.75 & 20.20 & 1.81 \\
\hline H 1 L 1 & 94.75 & 2.30 & 92.75 & 18.95 & 1.69 \\
\hline H2 L3 & 109.75 & 3.30 & 138.25 & 18.13 & 2.12 \\
\hline H6 L1 & 114.75 & 1.30 & 94.25 & 16.99 & 2.35 \\
\hline H2 L24 & 114.75 & 1.30 & 147.25 & 17.96 & 2.57 \\
\hline H11 L8 & 104.75 & 3.30 & 38.25 & 18.96 & 1.93 \\
\hline H11 L145 & 108.50 & 3.05 & 82.25 & 17.30 & 1.19 \\
\hline H15 L5 & 108.50 & 4.05 & 119.25 & 18.37 & 2.81 \\
\hline HC83-123-9 & 58.50 & 2.05 & 62.25 & 11.27 & 1.87 \\
\hline AGS 129 & 103.50 & 2.05 & 169.25 & 19.18 & 2.54 \\
\hline \multicolumn{6}{|l|}{ Check cultivars } \\
\hline Giza 35 & 94.00 & 2.60 & 72.00 & 18.65 & 2.15 \\
\hline Giza 82 & 96.00 & 2.80 & 52.60 & 16.80 & 1.31 \\
\hline Giza 111 & 100.00 & 2.40 & 68.00 & 16.35 & 2.35 \\
\hline Crawford & 109.00 & 3.40 & 89.40 & 18.72 & 2.05 \\
\hline \multicolumn{6}{|l|}{ LSD values } \\
\hline Among check cultivars & 4.68 & 0.83 & 13.77 & 1.27 & 0.26 \\
\hline gi vs gj (same block) & 13.22 & 2.36 & 38.96 & 3.58 & 0.73 \\
\hline gi vs gj (different blocks) & 14.78 & 2.63 & 43.56 & 4.01 & 0.82 \\
\hline Check vs tested genotypes & 10.84 & 1.93 & 31.93 & 2.94 & 0.60 \\
\hline
\end{tabular}

*PH, plant height; NOB, number of branches per plant; NOP, number of pods per plant; 100-SW, 100-seed weight (g) and SY, Seed yield.

(1.30) per plant. Genotypes; AGS 129 and Giza 22 significantly surpassed all tested and check genotypes considering number of pods per plant recording 169.25 and 167.75 branches, respectively. However, the lowest number of pods/plant were produced by H11L8 (38.25), Holladay (40.75) and H30 (45.0). Results in Table 2, also showed that the heaviest weights of 100 seeds were obtained by H113 (21.17 g) followed by H 30 (21.07 g) and Giza 21 (20.78g) while, the minimum seed index were obtained by HC83-123-9 (11.27 g). With respect to seed yield, results revealed that genotypes H15L5, H2L24, AGS 129 and Giza 22 gave the heaviest seed yield recording 2.81, 2.57, 2.54 and 2.52 ton/fed, respectively indicating their magnitude as promising genotypes and they could be recommended to be used in breeding pro- grams of soybean. Similar results were observed by Hassan et al. (2001) and (2002), Mohamed and Morsy (2005), Iqbal et al. (2008).

\section{Cluster analysis}

Results of cluster analysis are displayed in Table 4 and graphically illustrated in dendrogram Fig. 1. Results indicated that the lowest similarity level (less than 30) was recorded between two nodes (1 and 24) equaled 22.64. The next smallest similarity levels (less than 50) were obtained between genotype 1 (Giza 21) and each one of the three genotypes being Clark, Holladay and H30. Also, the similarity level between Giza 21 and Giza 22 was 53.36. Four pairs of genotypes revealed similarity levels are less than 70 being (Giza 21and H162), 
(Giza 21and Giza 35), (Giza 21and Crawford) and (Giza 22 and H6 L1) recording 62.71, 63.77, 68.41 and 68.74, respectively. From dendrogram, it is obvious that four pairs of genotypes (H 105 and H11 L145), (H32 and H1 L1), (Giza 35 and Giza 111) and (Crawford and H2 L3) are closely related to each other where the similarity levels among them were more than 80 recording 86.69, $85.81,80.83$ and 80.54 , respectively. On the other hand, the remainder similarity levels among the pairs of genotypes ranged between 70 and 80 .

Table 4. Cluster analysis to classify 24 genotypes of soybean based on agro-morphological traits

\begin{tabular}{|c|c|c|c|c|c|}
\hline \multirow{2}{*}{$\begin{array}{c}\text { No. of clusters } \\
23\end{array}$} & \multirow{2}{*}{$\begin{array}{c}\text { Similarity level } \\
86.69\end{array}$} & \multicolumn{2}{|c|}{ Clusters jointed } & \multirow{2}{*}{$\begin{array}{c}\text { New cluster } \\
11\end{array}$} & \multirow{2}{*}{$\begin{array}{c}\text { No. of entries in } \\
\text { new cluster }\end{array}$} \\
\hline & & 11 & 21 & & \\
\hline 22 & 85.81 & 10 & 16 & 10 & 2 \\
\hline 21 & 80.83 & 3 & 5 & 3 & 2 \\
\hline 20 & 80.54 & 8 & 17 & 8 & 2 \\
\hline 19 & 78.87 & 19 & 23 & 19 & 2 \\
\hline 18 & 77.54 & 4 & 11 & 4 & 3 \\
\hline 17 & 77.15 & 2 & 19 & 2 & 3 \\
\hline 16 & 76.65 & 10 & 13 & 10 & 3 \\
\hline 15 & 75.46 & 8 & 22 & 8 & 3 \\
\hline 14 & 73.75 & 3 & 10 & 3 & 5 \\
\hline 13 & 72.91 & 15 & 20 & 15 & 2 \\
\hline 12 & 71.98 & 9 & 12 & 9 & 2 \\
\hline 11 & 71.04 & 8 & 14 & 8 & 4 \\
\hline 10 & 70.83 & 3 & 4 & 3 & 8 \\
\hline 9 & 68.74 & 2 & 18 & 2 & 4 \\
\hline 8 & 68.41 & 1 & 8 & 1 & 5 \\
\hline 7 & 63.77 & 1 & 3 & 1 & 13 \\
\hline 6 & 62.71 & 1 & 15 & 1 & 15 \\
\hline 5 & 53.36 & 1 & 2 & 1 & 19 \\
\hline 4 & 49.37 & 1 & 9 & 1 & 21 \\
\hline 3 & 46.34 & 1 & 7 & 1 & 22 \\
\hline 2 & 45.22 & 1 & 6 & 1 & 23 \\
\hline 1 & 22.64 & 1 & 24 & 1 & 24 \\
\hline
\end{tabular}

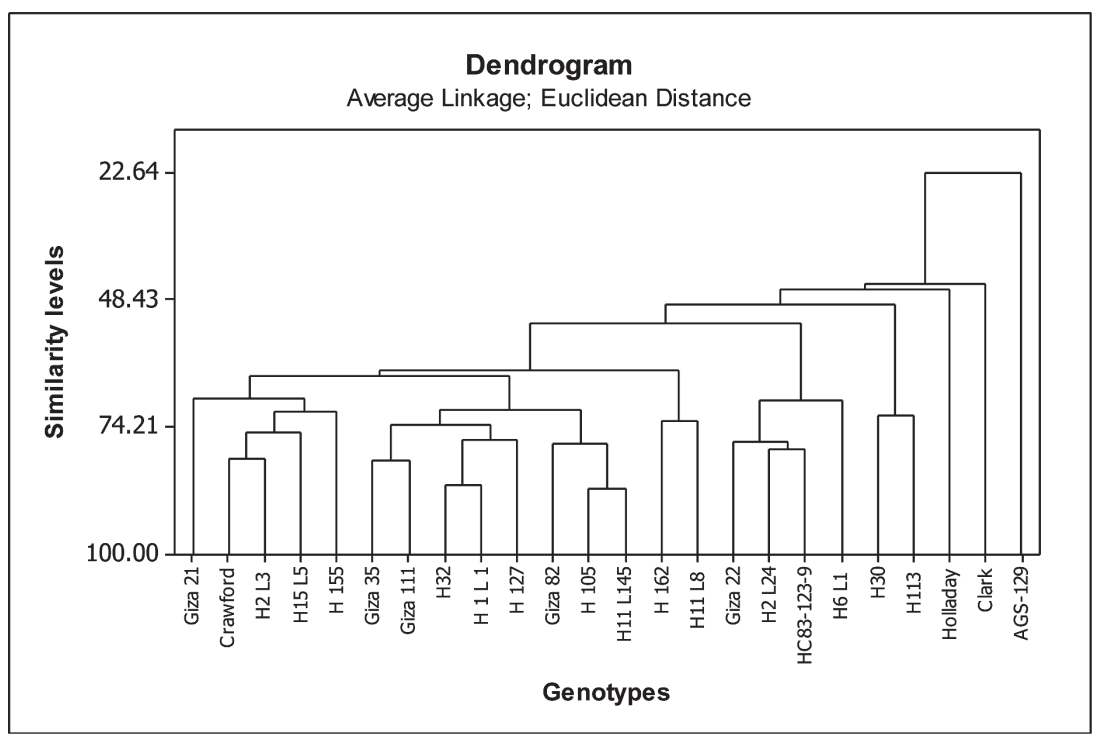

Fig. 1. Similarity levels for 24 soybean genotypes calculated by cluster analysis based on agromorphological traits. 
From the previous results, it could be concluded, based on similarity levels, that genotypes $24,6,7,9,2$, 15,3 and 8 have low similarity levels (dissimilarity) with genotype 1 (Giza 21) and may produce good results if they are crossed with. It is noteworthy that cluster analysis considered a valuable tool for subdividing number of genotypes in groups including similarity and dissimilarity genotypes which would help the breeder to plan an effective breeding program. These results are in harmony with those obtained by Iqbal et al. (2008) and Ojo et al. (2012).

\section{Molecular analysis}

Polymorphism was revealed in the banding patterns across the set of the studied 24 soybean genotypes. Among the used 14 SSR primer pairs, all of of them generated polymorphic bands. For a total of 14 primers 42 bands were obtained of which $(92.85 \%)$ were polymorphic and (7.15\%) were monomorphic bands as shown in Figure 2. The number of microsatellite alleles of used markers ranged from one to five alleles of which Satt173 and Satt181 markers produced the highest numbers of alleles ( 5 alleles) for both primers while Satt005 produced the lowest numbers of alleles (one allele) as a monomorphic band as shown in Table 5. Polymorphic information content (PIC) values were varied from 0.55 to 0.88 , the highest value belong to Satt173 (PIC 0.88) with five alleles which amplify core motif (ATT)18, while Satt001 showed the lowest PIC value $(\mathrm{PIC}=0.55)$ with three alleles, generally, SSR core motifs (ATT) gave higher allele numbers and PIC values than motifs (AT). Hence, primer Satt173 is highly informative in the present study; this indicated that the primer (Satt173) might be an effective and useful tool to determine the genetic differences among the soybean accessions and to study the phylogenetic relationship. The PIC observed in the present study is comparable to those reported by Gyu et al. (2008) who found lower PIC ranged from 0.43 to 0.82 . A slightly higher SSR diversity was reported by Fu et al. (2007), who found 6.3 alleles per locus (included null alleles)
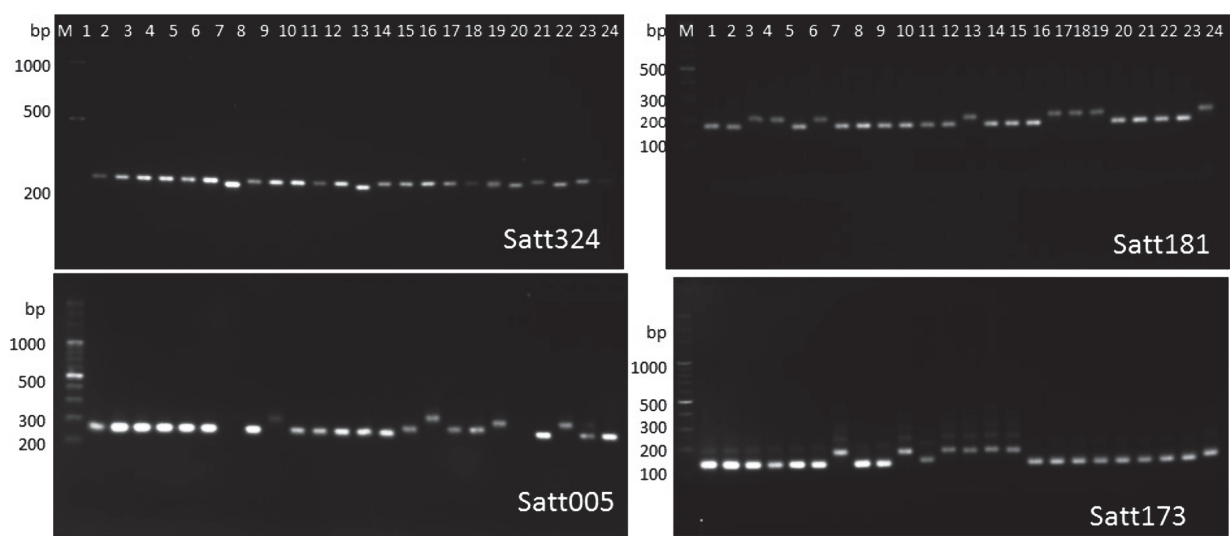

Fig. 2. DNA patterns of primer SSR; M, marker 100bp 1-24 soybean genotypes as shown in Table 1.

Table 5. Simple sequence repeat (SSR) No., of bands, Polymorphic, expected allele size, band size range and polymorphic information content (PIC)

\begin{tabular}{lcccccc}
\hline primer name & $\begin{array}{c}\text { Core } \\
\text { motif }\end{array}$ & $\begin{array}{c}\text { Number of } \\
\text { bands }\end{array}$ & $\begin{array}{c}\text { Polymorphic } \\
(\%)\end{array}$ & $\begin{array}{c}\text { Expected allele } \\
\text { size (bp) }\end{array}$ & $\begin{array}{c}\text { Band size } \\
\text { range }\end{array}$ & PIC \\
\hline Satt001 & (ATT)25 & 3 & 100.0 & 117 & $120-135$ & 0.55 \\
Satt002 & (ATT)25 & 2 & 100.0 & 127 & $125-140$ & 0.58 \\
Satt005 & (ATT)19 & 1 & 00.0 & 141 & 150 & 0.00 \\
Satt009 & (ATT)14 & 3 & 100.0 & 163 & $158-250$ & 0.77 \\
Satt030 & (ATT)21 & 2 & 100.0 & 164 & $170-180$ & 0.61 \\
Satt031 & (ATT)12 & 2 & 100.0 & 122 & $140-190$ & 0.63 \\
Satt173 & (ATT)18 & 5 & 100.0 & 197 & $160-200$ & 0.88 \\
Satt181 & (ATT)18 & 5 & 100.0 & 214 & $190-220$ & 0.73 \\
Satt324 & (ATT)19 & 4 & 100.0 & 250 & $220-230$ & 0.70 \\
Satt250 & (ATT) 16 & 4 & 100.0 & 202 & $190-210$ & 0.81 \\
Satt268 & (ATT)17 & 4 & 100.0 & 236 & $230-250$ & 0.74 \\
Sat_036 & (AT)19 & 3 & 100.0 & 142 & $145-150$ & 0.60 \\
Sat_168 & (AT)15 & 2 & 100.0 & 157 & $150-160$ & 0.59 \\
Sat_185 & (AT) 31 & 2 & 100.0 & 230 & $200-240$ & 0.76 \\
\hline
\end{tabular}


and an average polymorphic information content of 0.63 among 45 Canadian soybean cultivars and 37 exotic germplasm accessions analyzed at 37 SSR loci.
The constructed dendrogram tree revealed six main genetic clusters Figure 3. The first and second clusters comprise the highly diverged genotypes, H1L18, HC83-

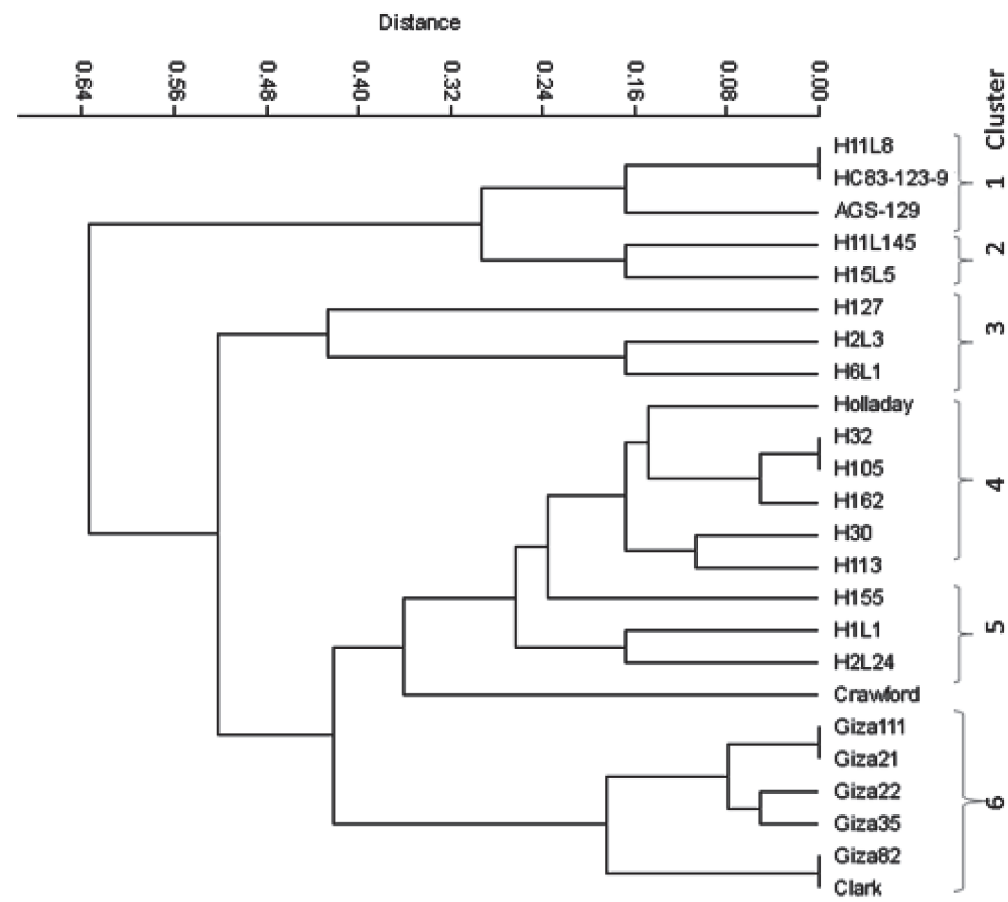

Fig. 3. UPGMA clusters analysis-based dendrogram depicting genetic relationships among 24 soybean genotypes using SSR markers.

Table 6. Distance index for SSR primer pairs based on Jukes and cantor for the studied 24 soybean genotypes

\begin{tabular}{|c|c|c|c|c|c|c|c|c|c|c|c|c|c|c|c|c|c|c|c|c|c|c|}
\hline & $\begin{array}{c}\text { Giza } \\
21\end{array}$ & $\begin{array}{c}\text { Giza } \\
22\end{array}$ & $\begin{array}{c}\text { Giza } \\
35\end{array}$ & $\begin{array}{c}\text { Giza } \\
82\end{array}$ & $\begin{array}{c}\text { Giza } \\
111\end{array}$ & Clark & $\begin{array}{l}\text { Holl- } \\
\text { aday }\end{array}$ & $\begin{array}{l}\text { Craw- } \\
\text { ford }\end{array}$ & H30 & H32 & H105 & H113 & $\mathrm{H} 127$ & H155 & H162 & $\begin{array}{l}\text { H1 } \\
\text { L1 }\end{array}$ & $\begin{array}{l}\mathrm{H} 2 \\
\text { L3 }\end{array}$ & $\begin{array}{l}\text { H6 } \\
\text { L1 }\end{array}$ & $\begin{array}{c}\mathrm{H} 2 \\
\mathrm{~L} 24\end{array}$ & $\begin{array}{c}\text { H11 } \\
\text { L8 }\end{array}$ & $\begin{array}{c}\text { H11 } \\
\text { L145 }\end{array}$ & $\begin{array}{c}\text { H15 } \\
\text { L5 }\end{array}$ \\
\hline Giza22 & 0.11 & 0.00 & & & & & & & & & & & & & & & & & & & & \\
\hline Giza35 & 0.05 & 0.05 & 0.00 & & & & & & & & & & & & & & & & & & & \\
\hline Giza82 & 0.23 & 0.11 & 0.17 & 0.00 & & & & & & & & & & & & & & & & & & \\
\hline Giza111 & 0.00 & 0.11 & 0.05 & 0.23 & 0.00 & & & & & & & & & & & & & & & & & \\
\hline Clark & 0.23 & 0.11 & 0.17 & 0.00 & 0.23 & 0.00 & & & & & & & & & & & & & & & & \\
\hline Holladay & 0.23 & 0.38 & 0.30 & 0.57 & 0.23 & 0.57 & 0.00 & & & & & & & & & & & & & & & \\
\hline Crawford & 0.30 & 0.47 & 0.38 & 0.69 & 0.30 & 0.69 & 0.17 & 0.00 & & & & & & & & & & & & & & \\
\hline H30 & 0.47 & 0.47 & 0.57 & 0.69 & 0.47 & 0.69 & 0.17 & 0.38 & 0.00 & & & & & & & & & & & & & \\
\hline H32 & 0.30 & 0.17 & 0.23 & 0.30 & 0.30 & 0.30 & 0.17 & 0.38 & 0.23 & 0.00 & & & & & & & & & & & & \\
\hline H105 & 0.30 & 0.17 & 0.23 & 0.30 & 0.30 & 0.30 & 0.17 & 0.38 & 0.23 & 0.00 & 0.00 & & & & & & & & & & & \\
\hline H113 & 0.30 & 0.30 & 0.38 & 0.47 & 0.30 & 0.47 & 0.17 & 0.38 & 0.11 & 0.11 & 0.11 & 0.00 & & & & & & & & & & \\
\hline H127 & 0.69 & 0.47 & 0.57 & 0.30 & 0.69 & 0.30 & 0.47 & 0.82 & 0.57 & 0.23 & 0.23 & 0.38 & 0.00 & & & & & & & & & \\
\hline H155 & 0.47 & 0.47 & 0.57 & 0.69 & 0.47 & 0.69 & 0.30 & 0.38 & 0.23 & 0.23 & 0.23 & 0.11 & 0.38 & 0.00 & & & & & & & & \\
\hline H162 & 0.38 & 0.23 & 0.30 & 0.38 & 0.38 & 0.38 & 0.11 & 0.30 & 0.17 & 0.05 & 0.05 & 0.17 & 0.30 & 0.30 & 0.00 & & & & & & & \\
\hline H1L1 & 0.69 & 0.47 & 0.57 & 0.69 & 0.69 & 0.69 & 0.30 & 0.38 & 0.38 & 0.23 & 0.23 & 0.38 & 0.38 & 0.23 & 0.17 & 0.00 & & & & & & \\
\hline H2L3 & 0.82 & 0.57 & 0.69 & 0.57 & 0.82 & 0.57 & 0.38 & 0.69 & 0.30 & 0.30 & 0.30 & 0.47 & 0.47 & 0.69 & 0.23 & 0.47 & 0.00 & & & & & \\
\hline H6L1 & 0.99 & 0.69 & 0.82 & 0.69 & 0.99 & 0.69 & 0.47 & 0.82 & 0.57 & 0.38 & 0.38 & 0.57 & 0.38 & 0.57 & 0.30 & 0.23 & 0.17 & 0.00 & & & & \\
\hline H2L24 & 0.38 & 0.23 & 0.30 & 0.38 & 0.38 & 0.38 & 0.23 & 0.47 & 0.30 & 0.17 & 0.17 & 0.30 & 0.47 & 0.47 & 0.11 & 0.17 & 0.38 & 0.30 & 0.00 & & & \\
\hline H11L8 & 0.82 & 0.82 & 0.99 & 0.82 & 0.82 & 0.82 & 0.57 & 0.69 & 0.69 & 0.69 & 0.69 & 0.69 & 0.69 & 0.47 & 0.57 & 0.47 & 0.82 & 0.69 & 0.82 & 0.00 & & \\
\hline H11L145 & 0.69 & 0.47 & 0.57 & 0.47 & 0.69 & 0.47 & 0.47 & 0.57 & 0.57 & 0.38 & 0.38 & 0.57 & 0.38 & 0.38 & 0.30 & 0.23 & 0.47 & 0.38 & 0.30 & 0.30 & 0.00 & \\
\hline H15L5 & 0.82 & 0.82 & 0.99 & 0.82 & 0.82 & 0.82 & 0.57 & 0.69 & 0.69 & 0.69 & 0.69 & 0.69 & 0.69 & 0.47 & 0.57 & 0.47 & 0.57 & 0.47 & 0.57 & 0.23 & 0.17 & 0.00 \\
\hline $\begin{array}{l}\text { HC83- } \\
123-9\end{array}$ & 0.82 & 0.82 & 0.99 & 0.82 & 0.82 & 0.82 & 0.57 & 0.69 & 0.69 & 0.69 & 0.69 & 0.69 & 0.69 & 0.47 & 0.57 & 0.47 & 0.82 & 0.69 & 0.82 & 0.00 & 0.30 & 0.23 \\
\hline
\end{tabular}


123-9 and AGS-129 in cluster 1 as new exotic introduced, H11L145 and H15L5 in cluster 2, while the third, fourth and fifth clusters includes three promising lines. On the other hand, the last cluster includes the Egyptian cultivars, Giza 21, Giza 22, Giza 111, Giza 35, Giza 82 and Clark with low diversity. The low distance value (low ranged from 0.00 to 0.2 ) were recorded among the Egyptian cultivars indicating that these cultivars were closely related to each other and this is reflect their pedigree as shown in Table 6. On the other hand, the highest values 99.0\% was recorded among the Egyptian cultivars and the exotic introduced in clusters 1 and 2 indicating that these cultivars were genetically distant than those exotic introduced genotypes.

In the present study, SSR markers were used to assess genetic variation of Egyptian soybean gene pool. This method provides an alternative choice to other system for obtaining highly reproducible markers. In fact several studies showed that domesticated soybeans have reduced genetic diversity, a changed distribution of alleles and in many other cases (Gizlice et al., 1994; Barakat, 2004; Min et al., 2010). On the other hand, (BrownGuedira et al., 2000; Mulato et al., 2010) found a high genetic variation among some exotic and wiled soybean germplams. The genetic relationships among genotypes based agro-morphological analysis not completely agreed with known pedigrees. However, phylogenetic tree based on SSR confirmed the separation of soybean genotypes into six groups and were more clearly separated. In the SSR analysis described in the present study, all the accessions used were cultivars and promising lines and no wild soybean was analyzed. Moreover, when we excluded the diverged genotypes in cluster 4,5 and 6 distance among the rest genotypes will be reduced. The information on the genetic diversity relationship from this study is propitious to develop novel soybean cultivars with good yield potential, resistant to biotic and abiotic stresses and accepted by soybean grower biased genetic transformation for cultivated soybean (Khatab and El-Banna, 2014) or mutation breeding (Khatab, unpublished data). It seems to be using introduces and exotic genotypes as distinct can be very useful for broadening the genetic base of soybean Egyptian cultivars. The results indicate that SSRs may constitute a relatively simple and efficient method for analyzing genetic variation in Egyptian soybean genotypes for future breeding programmers. To ensure sustaining breeding progress in the future, the introduction of new germplasm into these breeding programs, especially by the aid of molecular markers, is recommended.

\section{ACKNOWLEDGEMENTS}

We would like to thank to all staff of Plant Genetics Lab., Institute of Genetic Resources Fac., of Agri., Kyushu Univ., Japan for their support. Part of this work was done in Genetic Engineering and Tissue Culture Lab., (GETCL) Fac., of Agric., Kafrelsheikh Univ., Egypt.

\section{REFERENCES}

Abe, J., Y. Suzuki, A. Kanazawa and Y. Shimamoto 2003 Soybean germplasm pools in Asia revealed by nuclear SSRs. Theor Appl., Gen 106: 445-453

Anderson, J. A., G. A.Churchill, J. E. Autrique, S. D Tanksley and M. E, Sorrells. 1993 Optimizing parental selection for genetic linkage maps. Genome, $\mathbf{3 6}(1)$ : 181-186

Barakat, H. 2004 Genetic Fingerprinting and Relationships of Six Soybeans [Glycine max (L.) Merr.] Cultivars Based on Protein and DNAPolymorphis. J. Agri. Biol., 6: 877-883

Brown-Guedira G. L., J. A. Thompson, R. L. Nelson, and M. L. Warburton, 2000 Evaluation of Genetic Diversity of Soybean Introductions and North American Ancestors Using RAPD and SSR Markers. Crop Sci., 40: 815-823

Delannay, X., D. M. Rogers, and R. G. Palmer 1983 Relative genetic contributions among ancestral lines to North American soybean cultivars. Crop Sci., 23: 944-949

Doyle, J. J. and J. L. Doyle 1990 Isolation of plant DNA from fresh tissue. Focus, 12: 13-15

Federer, W. T. 1956 Augmented (or hoonuiaku) designs. Hawain Planters Record, 40: 191-207

Fu, Y. B., G. W. Peterson and M. J. Morrison 2007 Genetic Diversity of Canadian Soybean Cultivars and Exotic Germplasm Revealed by Simple Sequence Repeat Markers. Crop Sci., 47: 1947-1954

Gizlice, Z., T. E. Carter, Jr., and J. W. Burton 1994 Genetic base for North American public soybean cultivars released between 1947 and 1988. Crop Sci., 34: 1143-1151

Gyu, T. C., 2, Jeongran L., Jung-K. M., Mun S. and P. Paek 2008 Genetic Diversity and Population Structure of Korean Soybean Landrace [Glycine $\max$ (L.) Merr.]. J. Crop Sci. Biotech., 11(2): 83-90

Hammer, Ø. H., A.T. David and P. D. Ryan 2001 Past: Paleontological Statistics Software Package for Education and Data Analysis. Palaeontologia Electronica, 4: 4-9

Hartman G. L., E. D. West and T. K. Herman 2011 Crops that feed the world 2. Soybean-worldwide production, use, and constraints caused by pathogens and pests. Food Secur., 3: 5-17

Hassan, M. Z., Kh. A. Al-Assily, M. S. A. Mohamed and A. E. Sharaf 2002. Performance of some soybean cultivars under different sowing dates at the newly reclaimed lands of East Owinat and Kharga. Arab Univ., J. Agric. Sci., 10: 173-179

Hassan, M. Z., Kh. A. Al-Assily; Kh. A. Ali and A. E. Sharaf 2001 Evaluation some soybean cultivars at various plant population densities on the new reclaimed lands of East Owinat and Kharga. Arab Univ. J. Agric. Sci., 9: 615-622

Iqbal, Z., M. Arshad, M. Ashraf, T. Mahmood, and A. Waheed 2008 Evaluation of soybeen [Glycine $\max$ (L.) Merr.] germplasm for some important morphological traits using multivariate analysis. Pak.J. Bot., 40(6): 2323-2328

Khatab, A. I. and A. Morsy 2012 Evaluation of genetic relationships of some soybean genotypes using morphological and molecular markers. Annals of Agric., Sci.,, Moshtohor, Special issue, 2: $35-39$

Khatab, A. I. and A. N. El-Banna 2014 Establishment of a high efficiency Agrobacterium- mediated transformation conditions of soybean callus. Indian J. of biotechnology, 13: 459-463

Kovach, W. I. 1995 A multivariate statistics package for IBM PC and compatibles, Kovach Computing Service, 85 Nant-YFelin, Pentreaeth, Anglesely LL 758 UY Wales, U.K.

Li. Y., R. Guan, Z. Liu, Y. Ma, L. Wang, L. Li, F. Lin, W. Luan, P. Chen, Z. Yan, Y. Guan, L. Zhu, X. Ning, M. Smulders, W. Li, R. Piao, Y. Cui, Z. Yu, Guan M, R .Chang, A. Hou, A. Shi, B. Zhang, S. Zhu and L. Qiu 2008 Genetic structure and diversity of cultivated soybean [Glycine $\max (\mathrm{L}$.$) Merr.] landraces in China.$ Theor Appl Gen., 117: 857-871

Meesang, N., S. L. Ranamukhaara, M.J. Peterssen and S.B. Andersen 2001 Soybean cultivar identification and genetic purity analysis using microsatellite DNA markers. Seed Sci. Technol., 29 $637-645$

Min, W., L. Run-Zhi, Y. Wan-ming and S. Wei-jun 2010. Assessing the genetic diversity of cultivars and wild soybeans using SSR 
markers. Afr. J. Biotechnol., 9: 4857-4866

Mohamed, M. S. A. and F. M. Morsy 2005 Evaluation of some soybean genotypes in the new reclaimed lands of East Owinat. $J$. Agric. Sci., Mansoura Univ., 30(1): 79- 89

Mulato, B. M., M. I. Moller-Zucchi, V. Quecini and J. B. Pinheiro, 2010 Genetic diversity in soybean germplasm identified by SSR and EST-SSR markers. Pres. Agropec. Bras., 45: 276-283

Narvel, J. M., W. R. Fehr, W. Chu, D. Grant, and R. C. Shoemaker 2000 Simple sequence repeat diversity among soybean plant introductions and elite genotypes. Crop Sci., 40: 1452-1458

Ojo, D. K., A. O. Ajayi and O. A.Oduwaye 2012. Genetic relationships among soybean Accessions based on morphological and RAPDS Techniques. Pertanika J. Trop. Agric. Sci., 35(2): 237-248

Perry, M .C., and M. S. McIntosh 1991 Geographical patterns of variation in USDA soybean germplasm collection: I. Morphological traits. Crop Sci., 31: 1350-1355

Prioli R. H. G., C. T. Mended, N. E. Arantes and E. P. B. Contel 2002 Characterisation of Brazilian soybean cultivars using microsatellite markers. Genet. Mol. Biol., 25: 185-193

Sneller, C. H., J. W., Miles, and J. M. Hoyt 1997 Agronomic performance of soybean plant introductions and their similarity to elite lines. Crop Sci., 37: 1595-1600

Spehar C. R. $\quad$ 1994. Field screening of soya bean [Glycine max
(L.) Merr.] germplasm for aluminium tolerance by use of augmented design. Euphytica, 76: 203-213

Tantasawat, P., J. Trongchuen, T. Prajongjai, S. Jenweerawat and W. Chaowiset 2011 SSR analysis of soybean [Glycine max (L.) Merr.] genetic relationship and variety identification in Thailand. Australian J. of Crop Sci.; 5(3): 283-290

Tara S. C., Bhat K. V., Bharadwaj C., Tiwari S. P. and V. K. Chaudhury 2006 AFLP analysis of genetic diversity in Indian soybean [Glycine $\max$ (L.) Merr.] varieties. Genet Res Crop Evol., 53: 1069-1079

Thompson, J. A., R. L. Nelson, and L. O. Vodkin 1998 Identification of diverse soybean germplasm using RAPD markers. Crop Sci., 38: 1348-1355

Wang L., R. Guan, L. Zhangxiong, R. Chang and L. Qiu 2006 Genetic diversity of Chinese cultivated soybean revealed by SSR markers. Crop Sci., 46: 1032-1038

Yoon, M., J. Lee, C. Kim, J. Kang, E. Cho and H. Baek 2009 DNA profi ling and genetic diversity of Korean soybean [Glycine $\max$ (L.) Merr.] landraces by SSR markers. Euphytica, 165: $69-77$

Zhenbin H., D. Zhang, G. Zhang, G. Kan, D. Hong and D. Yu 2014 Association mapping of yield-related traits and SSR markers in wild soybean [Glycine soja Sieb. and Zucc.]. Breeding Sci., 63: 441-449 